\title{
Viral Encephalitis: Etiology, Clinical Features, Diagnosis and Management
}

\author{
Sergio Ferrari ${ }^{1}$, Antonio Toniolo ${ }^{2}$, Salvatore Monaco $^{1}$, Filippo Luciani ${ }^{3}$, Francesca Cainelli ${ }^{4}$, \\ Andreina Baj $^{2}$, Zelalem Temesgen ${ }^{5}$ and Sandro Vento ${ }^{*}, 3$ \\ ${ }^{I}$ Department of Neurological and Visual Sciences, Section of Neurology, University of Verona, Verona, Italy \\ ${ }^{2}$ Laboratory of Medical Microbiology, University of Insubria, Varese, Italy \\ ${ }^{3}$ Infectious Diseases Unit, Annunziata Hospital, Cosenza, Italy \\ ${ }^{4}$ Department of Emergency Medicine, Annunziata Hospital, Cosenza, Italy \\ ${ }^{5}$ Division of Infectious Diseases, Mayo Clinic College of Medicine, Rochester, MN, USA
}

\begin{abstract}
Viral encephalitis is worldwide spread pathology with high morbidity and mortality. Its incidence is higher in children. Enteroviruses, varicella zoster virus and herpes simplex viruses are the most frequent agents. However, in spite of the use of modern microbiological and radiological methods, an etiological diagnosis is reached in less than $50 \%$ of cases, making a careful differential diagnosis with non viral brain diseases imperative. Pathogenesis is elusive and therapy continues to remain supportive in almost all cases, as the only virus-directed treatment is available for herpesvirus-related encephalitis and a role for steroids continues to be debated. Novel and more targeted therapies are eagerly needed.
\end{abstract}

\section{INTRODUCTION}

Encephalitis is an inflammation of the brain parenchyma usually caused by bacteria or viruses, and often associated with meningitis. Viruses vary widely in their potential to produce central nervous system (CNS) infection: for example, rabies virus inevitably and exclusively causes CNS disease, whereas encephalitis is a less common manifestation of infections caused by herpes simplex or varicella zoster viruses. The spectrum of brain involvement and the outcome of the disease are dependent not only on the specific pathogen, but also on the immunological state of the host and on a range of environmental factors. We will focus this review on the most relevant agents of clinically important viral encephalitis: herpes simplex virus 1 (HSV-1), varicella zoster virus (VZV), enteroviruses, Epstein-Barr virus (EBV), Tick borne (TBE), human herpesvirus 6 (HHV-6), measles virus (MV, the agent of subacute sclerosing panencephalitis, SSPE), rabies, West Nile Virus (WNV), Human immunodeficiency virus (HIV). We will not consider more recently described viruses, such as Nipah or Japanese encephalitis viruses, as these have been thoroughly examined in recent reviews. Tables 1a-c list the main agents of viral encephalitidis.

\section{Epidemiology}

Viral encephalitis is of public health concern worldwide because of its high morbidity and mortality as well as considerable economic costs. Incidence varies between studies but is generally between 3.5 and 7.4 per 100,000 patientyears [1], and is higher in children. Although both genders are affected, most studies have shown a slight predominance in males. Unfortunately, few population-based studies have

*Address correspondence to this author at the Infectious Diseases Unit, Annunziata Hospital, 87100 Cosenza, Italy; Tel/Fax: 39.0984.681360;

E-mail: ventosandro@yahoo.it been done, the disease is underreported, and in many cases the cause remains obscure. Data on the incidence of different etiological agents are contradictory. For example, a collaborative study done in Finland using gene amplification to detect various viruses in CSF samples of 3231 patients with encephalitis, meningitis, and myelitis, reported VZV as the most frequently involved agent (29\% of cases). HSV and enteroviruses accounted for $11 \%$ of cases each and influenza A virus for $7 \%$ of cases [2]. In contrast, in a recent report from Turku (Finland) of 144 consecutive adults with encephalitis or aseptic meningitis, viral etiology was recognised in 72 patients; $46 \%$ of these cases were attributed to enteroviruses, $31 \%$ to HSV-2, $11 \%$ to VZV, and $4 \%$ to HSV-1 [3]. The difference may be partly explained by the fact that in the latter paper, the authors examined only immunocompetent adults, patients with meningitis and encephalitis were analysed separately, and the 5-year study period was long enough to reduce effects of epidemics and seasonal variation. HSV-1/2 cause the most severe forms of infections of the human brain. Currently, herpes simplex encephalitis (HSE) is estimated to occur in approximately 1 in 250,000 to 1 in 500,000 individuals per year [4]. In the US the estimated incidence is approximately 1 in 300,000 individuals [4], similar to those in England [5] and Sweden [6]. HSE occurs throughout the year and in patients of all ages. Around onethird of cases occurs between 6 months and 20 years of age; approximately half of the patients are older than 50 years [7]. Both genders are equally affected.

\section{Pathogenesis and Histopathology}

Viruses access the CNS by either the neuronal or haematogenous route [8-10]. The latter is most common and in arthropod-borne infections is associated with alterations of the blood-brain barrier. In TBE transient viraemia follows viral replication in the skin after an insect bite, with consequent 
Table 1. Selected Etiologic Agents of Viral Encephalitis

\section{(a) DNA Viruses}

\begin{tabular}{|c|c|}
\hline \multirow{4}{*}{ Herpesviridae } & Herpes Simplex Virus (HSV) \\
\cline { 2 - 2 } & Varicella- Zoster Virus (VZV) \\
\cline { 2 - 2 } & Epstein-Barr Virus (EBV) \\
\cline { 2 - 2 } & Cytomegalovirus (CMV) \\
\cline { 2 - 2 } Polyomaviridae & Human Herpes Virus-6 (HHV-6) \\
\cline { 2 - 2 } & JCV \\
\hline Adenoviridae & BKV \\
\hline
\end{tabular}

\section{(b) RNA Viruses}

\begin{tabular}{|c|c|}
\hline Picornaviridae & Enteroviruses Poliovirus \\
\hline Retroviridae & Human Immunodeficiency Virus-1/2 (HIV-1/2) \\
\hline Rabdhoviridae & Rabies \\
\hline \multirow{2}{*}{ Paramyxoviridae } & Mumps \\
\cline { 2 - 2 } & Measles \\
\hline
\end{tabular}

(c) Arbovirus Group

\begin{tabular}{|c|c|c|}
\hline \multirow{3}{*}{ Togaviridae } & \multicolumn{2}{|c|}{ Eastern Equine Encephalitis (EEE) } \\
\hline & \multicolumn{2}{|c|}{ Western Equine Encephalitis (WEE) } \\
\hline & \multicolumn{2}{|c|}{ Venezuelan Equine Encephalitis (VEE) } \\
\hline \multirow{8}{*}{ Flaviviridae } & \multicolumn{2}{|c|}{ St Louis Encephalitis (SLE) } \\
\hline & \multicolumn{2}{|c|}{ West Nile Virus (WNV) } \\
\hline & \multicolumn{2}{|c|}{ Japanese Encephalitis (JE) } \\
\hline & \multicolumn{2}{|c|}{ Powassan Virus (POW) } \\
\hline & \multicolumn{2}{|c|}{ Murray Valley Encephalitis (MVE) } \\
\hline & \multirow{3}{*}{$\begin{array}{c}\text { Tick-Borne } \\
\text { Encephalitis Viruses } \\
\text { (TBEV) }\end{array}$} & $\begin{array}{c}\text { Far Eastern Subtype } \\
\text { (FE-TBEV) }\end{array}$ \\
\hline & & Siberian Subtype (S-TBEV) \\
\hline & & Western Subtype (W-TBEV) \\
\hline \multirow{3}{*}{ Bunyaviridae } & \multirow{2}{*}{ California Group } & California Virus \\
\hline & & La Crosse Virus (LAC) \\
\hline & Sandfly Fever Group & Toscana Virus (TOSV) \\
\hline
\end{tabular}

invasion of the reticuloendothelial system. Secondary viraemia leads to infection of other organs, including the CNS. In acute viral encephalitis, a remarkable pathological finding is the infiltration of mononuclear inflammatory cells in the Wirchow-Robin spaces and in the meninges around the wall of vessels (perivascular cuffing). With further disease progression, astrocytosis proliferation and hypertrophy of microglial cells with formation of microglial aggregates (microglial nodules) and neuronophagia (clusters of microglial cells surrounding a dead neuron) become prominent histopathological findings. The majority of inclusions are intranuclear but the only pathognomonic one is the intracytoplasmic
Negri body in rabies. The pathologic changes induced by replicating HSV include ballooning of infected cells and intranuclear eosinophilic amorphous or droplet-like bodies surrounded by a clear halo, with chromatin margination at the nuclear membrane (Cowdry type A inclusions). Intranuclear type A inclusions are similar in HSV, VZV and CMV; a better identification of the viral particles is obtained through electron microscopy, immunohistochemical and in situ hybridisation techniques. An influx of mononuclear cells in infected tissue ensues. HSE is associated with acute inflammation, congestion, and/or haemorrhage, most prominently in temporal lobes and usually asymmetrically in adults. Adjacent limbic areas are also involved, and the meninges overlying temporal lobes may be congested. Approximately two weeks later, frank necrosis of the involved brain areas occur.

Access to CNS by the intraneuronal route occurs typically in rabies (limbic system), and in HSV infections. Once the virus has reached the brain, it may remain confined to a few cells or spread to adjacent tissues either by cell-to-cell transmission or through extracellular spaces; afterwards, HSV may remain in a latent state within the CNS $[11,12]$.

Though largely investigated, the pathogenesis of HSE in children older than 3 months, adolescents and adults remains somewhat obscure. Both primary (in around one-third of the cases, generally younger than 18 years of age) and recurrent HSV infections can cause encephalitis. Of the two-thirds of cases occurring in the presence of pre-existing antibodies, only $10 \%$ of patients have a history of recurrent herpes labialis. Patients with pre-existing antibodies are thought to have HSE as a consequence of HSV reactivation [13]. Interestingly, when the genomic DNA from peripheral (labial) and CNS isolates are compared by restriction analysis, usually identical, but also different isolates are recovered [14]. The access of HSV to CNS in primary infection is still debated, with both the olfactory and trigeminal nerves proposed as prevailing routes. In patients with HSE, HSV particles have been demonstrated by electron microscopy along the olfactory tract in some individuals $[15,16]$. Animal models support the view that the olfactory tract provides an entry route into the CNS thus causing localisation of infection in brain regions analogous to the medial temporal structures of humans $[17,18]$. Where does reactivation of latent virus occur? Reactivation within the brain tissue has not been demonstrated. Although it has been proposed that this event takes place in the olfactory bulb or the trigeminal ganglion, with subsequent neuronal transmission to the CNS [17], it should be noted that HSE is rarely associated with recurrent herpes labialis. What about host immunity? It is conceivable that the $\mathrm{CNS}$ is particularly prone to HSV infection since intraneuronal spread hides the virus from host defence mechanisms. The picture is further complicated by the observation that the HSE prevalence is the same both in normal and immunosuppressed hosts. However, the presentation is atypical in immunosuppressed individuals with a subacute and progressively deteriorating course [19].

\section{Clinical Presentation}

Viral encephalitis can present in forms of low or mild severity that heal spontaneously or in much more aggressive forms with a poor prognosis and severe neurological sequelae in survivors. The prodromal signs and symptoms are 
those of a classic viral infection: fever and headache, possibly accompanied by lymphadenophathy, nausea or vomiting. After a few days, symptoms of CNS involvement become manifest with altered mental status, considerable irritability and agitation, personality changes; seizures (focal or generalised) may occur, sometimes accompanied by focal neurological signs. Patients may then become lethargic or comatose; death eventually ensues. Stiff-neck is a sign of meningeal involvement.

Fever is one of the most frequent features at presentation, and its absence should cast doubts on diagnosis. Prognosis is poorer in infants younger than 1 year and adults over 55 . Young children may have a stormy course for several days because of severe cerebral oedema.

\section{Enterovirus Encephalitis}

Enteroviruses seem to account for the majority of cases of viral encephalitis both in children and adults [20]. Infection is seasonal in temperate climates (summer and autumn peaks) but high the year round in tropical and subtropical climates. Although enteroviral encephalitis may be accompanied by mucocutaneous manifestations, including localised vesicles (e.g. hand, foot, and mouth disease), herpangina, and generalised maculopapular rash, these symptoms can be absent. Over the last 10 years, outbreaks of neurovirulent Enterovirus 71 have been reported from Japan, Malaysia, and Taiwan. A high mortality rate $(19.3 \%)$ has been reported from Taiwan in children below 5 years of age [21].

Unfavourable outcomes (death or neurological sequelae) of enteroviral encephalitis have been associated with younger age ( $<4$ years), high peak leukocyte counts ( $>$ $13,000 / \mathrm{mm}^{3}$ ), seizures, skin rash, myoclonic jerks, lower CSF viral yield rate, oral ulcers, enterovirus 71 as etiologic agent [21].

\section{Herpes Simplex Encephalitis (HSE)}

In HSE grey matter dysfunction of temporal and frontal lobes is a dominant feature, and the disease presents with personality changes, confusion, and disorientation. Seizures occur in half of the patients, focal neurological signs (hemiparesis) in about a third. Since prognosis is dependent on early initiation of treatment, there is a need for immediate and accurate diagnosis. For this reason, lumbar puncture should be preceded by neuroimaging only when focal neurological signs are present. CSF is abnormal in more than $95 \%$ of HSE cases; moderate pleocytosis is found, usually both of mononuclear white blood cells and red blood cells, the latter due to the haemorrhagic nature of the infectious process.

\section{Varicella Zoster Encephalitis}

VZV encephalitis occurs mainly in young adults and infants [22]. Seizures occur in 29 to $52 \%$ of cases. Focal neurological abnormalities include ataxia, hypertonia or hypotonia, hemiparesis, and positive plantar responses. Mortality varies from 5 to $10 \%$ [23]. Intranuclear inclusions and haemorrhagic necrosis, suggestive of varicella encephalitis, have been reported also in immunocompromised patients and in neonates [24].

\section{Epstein Barr virus (EBV) Encephalitis}

EBV encephalitis may involve not only temporal lobes but also different sites, including the cortex, brainstem and basal ganglia. Importantly, signs and symptoms of infectious mononucleosis, such as pharyngitis, adenopathy, splenomegaly, and atypical lymphocytosis are often absent $[25$, 26]. IgM against viral capsid antigens can be undetectable [27]. CSF abnormalities, if present, are subtle, with mild increase in pressure, mild mononuclear pleocytosis $(\leq 300$ cells $/ \mathrm{mm}^{3}$ in one series) [26] and slightly elevated proteins. Diagnosis is suggested by the occurrence, in more than a third of patients, of movement disorders, such as chorea, and focal disturbances (hemiparesis) [26]. Although EBV encephalitis runs frequently a benign course, neurologic sequelae may occur [26] and the disease can occasionally be fatal [27].

\section{Human Herpesvirus 6 (HHV-6) Encephalitis}

HHV-6, the causal agent of exanthema subitum, infects nearly all children by 3 years of age; two variants, A and B, have been identified [28]. Both of them are neurotropic in vivo and reside latently in the adult brain, complicating attempts to link HHV-6 to neurological disease [29]. However HHV-6 is considered a possible cause of encephalitis in immunosuppressed children. In patients undergoing allogeneic haematopoietic stem cell transplantation, a form of acute limbic encephalitis (characterised by anterograde amnesia, inappropriate $\mathrm{ADH}$ secretion syndrome, mild CSF pleocytosis, temporal EEG abnormalities) has been linked to HHV-6 [30]. Recently, HHV-6-associated rhombencephalitis, presenting with seizures, ataxia, and myoclonus, has been described in immunocompetent children [31]. Rare cases of encephalitis have been attributed to HHV-6 in adults [3237].

\section{Tick-Borne Encephalitidis}

Viruses transmitted to humans by tick-bite are important causes of CNS infections worldwide. TBE is caused by two strictly but biologically distinct flaviviruses. Seasonal outbreaks occur in rural areas of Russia (Russian SpringSummer Encephalitis, RSSE) and in Central Europe (Central European Encephalitis, CEE); transmission is mediated by the hard ticks Ixodes persulcatus and Ixodes ricinus, respectively (I. ovatus and I. gibosus may be additional vectors). The incubation period is 2 to 28 days. The clinical presentation of RSSE and CEE is similar, but RSSE is generally monophasic whereas CEE normally occurs in two stages. Severe cases are more frequent in RSSE. Importantly, around $30 \%$ of TBE patients do not recall any tick bite [38]. CEE is heralded by a few days of fever, headache, and muscle pain, followed by an asymptomatic period (2-10 days); later, symptoms and signs of encephalitis ensue. The mortality rate of RSSE is up to $25 \%$, whereas in CEE it does not exceed $4 \%$ [39]. Recovery from severe cases is slow, and $20 \%$ of patients may have severe neurologic sequelae.

\section{Measles Encephalitis}

In MV infection, CNS involvement can occur early or late after acute measles, causing acute and subacute forms of encephalitis. Acute postinfectious measles encephalitis generally occurs in immunocompetent patients (mostly children and adolescents) during the exanthematic phase and within 8 days after clinical onset [40]. The mortality rate is between 10 and $20 \%$, while sequelae are observed in 20 to $40 \%$ of patients who recover [40]. Onset of encephalitis at a later 
phase results either in measles inclusion body encephalitis (MIBE) or in subacute sclerosing panencephalitis (SSPE). MIBE is a subacute/chronic neurologic disease that may be observed in immunosuppressed children and young adults.

SSPE is a demyelinating CNS disease occurring several years (generally 6-8) after acute measles infection, with a prevalence of 1 in 100,000 to 1 in 1 million infected children. The disease has an insidious onset characterised by cognitive deterioration, poor school performance, ataxia, behavioural changes, myoclonus, possibly seizures, and chorioretinitis with partial visual deficit. Although progression differs in time and remissions may occur, death invariably occurs within 1 to 3 years [41]. Mutant MV strains (SSPE virus) can be recovered from the brain tissue of SSPE patients.

\section{Rabies}

Rabies is the only human infection causing acute encephalitis with a near- $100 \%$ mortality rate. The incubation period varies from 5 days to over 6 months, but is usually of 20-60 days [42]. After a prodromal period of malaise, anxiety, pain or itching at the site of bite, and fever, patients develop encephalopathic (hyperactivity and characteristic hydrophobic spasms of the sternomastoid, diaphragm and other inspiratory muscles, typical of the so called 'furious rabies') or paralytic neurological signs. Respiratory and heart failure following hydrophobic spasms are deadly in one-third of cases. Other clinical findings include Cheyne-Stokes respiration, III, IV and IX cranial nerves palsies and signs of the amygdaloid nuclei damage. Intermittent episodes of hallucinations and maniacal behaviour are also observed. Without intensive care, the illness leads to coma, flaccid paralysis and death in few days from onset.

\section{West Nile Virus}

West Nile virus, a flavivirus maintained worldwide in an enzootic cycle and transmitted primarily between avian hosts and mosquito (genus Culex) vectors, can occasionally infect humans, but most individuals remain asymptomatic. Symptoms may develop in $20-40 \%$ of subjects $[43,44]$ after an incubation period of 2-14 days. The vast majority of symptomatic patients present with flu-like symptoms (West Nile fever), i.e. fever, headache, malaise, myalgia, fatigue, skin rash, lymphadenopathy, vomiting, diarrhoea [45]. Less than $1 \%$ of infected individuals develop neuroinvasive diseases, i.e. meningitis, encephalitis, and/or acute flaccid paralysis. Although clinical features of these syndromes may overlap in the same patient, a large study of 228 patients found that most patients can be classified as either having meningitis or encephalitis and that patients with the latter have a higher mortality rate and more severe complications [46].

West Nile encephalitis follows selective neuroinvasion in certain cell populations (substantia nigra in brainstem, basal ganglia [47] and cerebellum) and is characterised by altered consciousness, disorientation, focal neurological signs and symptoms (dysarthria, seizures, tremor, ataxia, involuntary movements, parkinsonism) [46, 47].

\section{Human Immunodeficiency Virus}

During primary HIV infection, neurological manifestations, ranging from severe and persistent headache to clinical signs suggestive of encephalitis and/ormeningitis, can occur.
Headache and fever are prominent symptoms [48]. HIVRNA levels are high in cerebrospinal fluid. Although recovery without antiretroviral drugs usually follows, these can be administered to try and speed it.

Patients with chronic HIV infection can also, albeit rarely, develop acute neurologic syndromes while having very elevated cerebrospinal fluid HIV loads. Resolution of symptoms after changes in, or initiation of, antiretroviral therapy occur [49].

\section{Immune-Mediated Post-Infectious Inflammatory En- cephalopathies}

In addition to acute viral-induced brain damage, immunemediated inflammatory encephalopathies can be observed days to a few weeks after a viral (rubella, mumps, measles, EBV, VZV, influenza) or bacterial infection, but also following vaccination, especially with smallpox and rabies vaccines.

This condition, named acute disseminated encephalomyelitis (ADEM), must be distinguished from infectious encephalitis and non-infectious encephalopathies. ADEM is typically monophasic, with multifocal symptoms appearing within days, or sequentially over weeks, either in the presence or absence of fever and meningismus [50]. Neurological symptoms (including focal motor and sensory deficits, optic neuritis, cranial neuropathies, seizures, myoclonus, and ataxia) mainly correlate with demyelinating white matter changes at brain MRI, although inflammatory foci affect the cortical and subcortical grey matter. An acute variant of ADEM, named acute hemorrhagic leucoencephalomyelitis, is a rare and usually fatal condition. ADEM and its variants should be differentiated from demyelinating-like, ischemic, and haemorrhagic lesions observed in large- and smallvessel arteritis caused by VZV infection, and, in addition, from other demyelinating diseases, including multiple sclerosis-like syndromes associated with primary HHV-6 infection. In rare cases, transverse myelitis, optic neuritis, and neuromyelitis optica occur as isolated manifestations of ADEM. The range of post-infectious neurological complications is not limited to CNS, but includes also a bulbar variant of acute inflammatory demyelinating neuropathy (AIDP) after VZV infection, and acute brachial plexopathy in patients with antecedent CMV disease [51]. These disorders should be differentiated also from acute flaccid paralysis secondary to flaviviruses of the TBE complex, non-polio enteroviruses, coxsackievirus, and paralytic rabies.

\section{Non-Infectious Diseases Mimicking Viral Encephalitis}

A wide spectrum of acute, subacute, and chronic medical conditions involving the CNS present with neurological signs and symptoms that may overlap with those observed in the course of viral encephalitis, myelitis, and encephalomyelitis (Table 2).

While a detailed discussion of these disorders is beyond the scope of this review, we point to specific clues in clinical presentation, imaging findings and laboratory results that may be of help for differential diagnosis. In approaching a patient with suspected encephalitis it is important to define the neurological syndrome, assess whether the observed functional or structural CNS alterations involve the grey or white matter or both, obtain evidence of inflammation, and 
Table 2. Non-Infectious Diseases Mimicking Viral Encephalitis

\begin{tabular}{|c|l|}
\hline \multicolumn{1}{|c|}{ Condition } & \multicolumn{1}{c|}{ Diagnostic Features } \\
\hline \hline Limbic Encephalitis & $\begin{array}{l}\text { Anti-Hu, -Ma2, -amphiphysin, -CRMP5/CV2 (all frequently associated with cancer), -VGKC, -NMDA } \\
\text { receptor }\end{array}$ \\
\hline Hashimoto's Encephalitis & Anti-thyroid peroxidase, anti-thyroid microsomal antibodies \\
\hline Sjögren Sindrome & Anti-SSA/Ro, -SSB/La antibodies \\
\hline Systemic Lupus Erythematosus (SLE) & Anti-nuclear, -double-stranded DNA, antiphospholipid antibodies \\
\hline Acute Disseminate Encephalomyelitis (ADEM) & Predominant demyelinating lesions at brain MRI \\
\hline Vasculitis of CNS & CNS angiography, ANCA \\
\hline Bulbar Variant of GBS & CSF albuminocytological dissociation \\
\hline Primary and Metastatic Brain Tumours & CNS imaging \\
\hline Metabolic and toxic diseases & Liver and renal function toxicology screening \\
\hline Epileptic status & EEG recordings \\
\hline
\end{tabular}

Abbreviations: ANCA: antineutrophil-cytoplasmic antibodies; CNS: central nervous system, CSF: cerebrospinal fluid; GBS: Guillain-Barré syndrome; EEG: electroencephalography; NCSs: nerve conduction studies; NMDA: N-methyl-D-aspartate; SSA: Sjögren syndrome antigen A; SSB: Sjögren syndrome antigen B; VGKC: voltage-gated potassium channels.

rule out non-infective conditions. Typically, viral encephalitis presents as an acute febrile illness characterised by headache, decreased consciousness, focal seizures and focal neurological signs, as well as CSF markers of inflammation. Within this setting, acute viral encephalitis should be easily separated, on clinical grounds, from disorders causing aseptic meningitis, which manifests with fever, headache, cervical pain and neck stiffness. However, differential diagnosis is not as simple as it may appear. HSE, for example, has generally an abrupt-onset with confusion, severe impairment of episodic and semantic memory, uni- or bilateral temporal seizures, often accompanied by other focal signs. In rare cases, fever may be absent [52]. However, at clinical onset the above clinical features - that reflect involvement of orbito-frontal brain regions and medial temporal lobes - may partly overlap with those observed in transient disorders, such as cerebral concussion, psychiatric conditions, transient global amnesia, and temporal seizures [53].

In addition, a number of static disorders of the temporal lobe, including vascular, neoplastic, and infectious conditions, may closely mimic the florid phenotype of HSE [53]. In particular, autoimmune limbic encephalitis (a subacute neurological syndrome characterised by cognitive impairment, hallucinations, epileptic seizures, depression, and severe memory deficit) must be considered in the differential diagnosis [54]. Further overlap with HSE and, in turn, with limbic encephalitis may occur in patients with steroidresponsive encephalopathy associated with autoimmune thyroiditis (SREAT), also referred to as Hashimoto's encephalitis (a pleomorphic disorder characterised by high titres of antithyroid antibodies, hyperproteinorrachia, and variable EEG changes) [55]. Patients with SREAT present with acute/subacute myoclonus, altered consciousness, seizures, neuropsychiatric changes, and stroke-like deterioration. Importantly, steroid-responsiveness is typical of SREAT and other encephalopathic disorders belonging to the group of 'nonvasculitic autoimmune meningoencephalitis' (NAIM) [56], such as Sjögren's syndrome and systemic lupus erythematosus.
In limbic encephalitis symptoms are secondary to dysfunction of the limbic system (hippocampus, amygdala, hypothalamus, insular and cingulate cortex) as a consequence of cellular- and/or humoral-mediated autoimmune attack [57]. Limbic encephalitis is usually paraneoplastic, and mostly associated with distant and occult tumours, including small cell lung cancer, testicular seminomas, nonseminomatous germ-cell tumours, and lymphoma. Importantly, in a substantial number of patients, limbic encephalitis is unrelated to cancer and in such cases it may well respond to treatment [58]. The diagnosis of autoimmune limbic encephalitis is unequivocally obtained by demonstrating the presence of circulating autoantibodies recognizing either (a) intracellular onconeuronal antigens (e.g., Hu, Ma2, amphiphysin, and CRMP5/CV2), or (b) neuronal membrane antigens (e.g., N-methyl-D-aspartate receptor, voltage-gated potassium channels) [54, 58].

EEG recordings, magnetic resonance imaging (MRI) of the brain, and CSF examination are the essential first steps for differentiating viral infection from limbic encephalitis, SREAT, NAIM, granulomatous diseases, and primary vasculitis. In cases where MRI is of little help, brain positron emission tomography (PET) scan can provide diagnostic clues. Intriguingly, a limbic encephalitis syndrome, with confusion, altered sleep, temporal seizures, and memory impairment has been reported in immunocompromised, transplanted patients with HHV-6 reactivation [59].

Paraneoplastic conditions, such as brain-stem encephalitis, should be ruled out in the diagnostic workout of patients with rhombencephalitis, a rare brainstem syndrome presenting with myoclonus, ataxia, intention tremor, ocular disturbances, cranial nerve palsies, urinary retention, and, in fatal cases, neurogenic pulmonary oedema and shock. Rhombencephalitis is usually associated with bacterial infections, including Listeria monocytogenes, Mycoplasma pneumoniae, and Borrelia burgdorferi. Sporadic, self-limited, and benign forms have also been attributed to HSV, influenza A, adenovirus, echovirus, and flavivirus infections. In contrast, a rapidly evolving fatal course may occur following EBV and 
VZV infections. Recently, fatal outbreaks of enterovirus 71 rhombencephalitis have also been reported [60].

\section{Detection}

\section{Viral Sequences in CSF Samples}

Although over 100 viral agents can cause encephalitis, in clinical practice identification of the etiologic agent is still rare. Diagnosis was once accomplished by demonstrating intrathecally-produced antiviral antibodies. However, antibody assays are restricted to a few reference laboratories, require considerable time, and interpretation of results is complicated by the low antibody levels found in CSF as well as by passive transfer of antibodies from blood. This makes determination of $\mathrm{CSF} /$ serum antibody ratios mandatory.

Nowadays, nucleic acid (NA) technology is capable - in principle - of detecting genomes of any viral species. Molecular methods are characterised by the high sensitivity and rapidity (6 hours or less) that would allow the prompt initiation of antiviral therapy. Indeed in CSF samples NA technology retains sensitivity for some time after initiation of antivirals [61]. Since quantification of genome copy numbers may be a marker of disease severity and often predicts clinical outcome, quantitative methods are being increasingly applied to estimate the viral load and to monitor, for some viruses (e.g., HSV), the effects of antivirals [62].

Laboratory diagnosis begins with the NA extraction from CSF (rarely from brain biopsy). To this end, commercial methods are preferred for their effectiveness, and standardisation. Recently introduced, automated methods based on NA-binding magnetic particles are characterised by high purity of extracted NA. In our experience, manual methods continue to be satisfactory due to the low numbers of specimens usually submitted to laboratories for suspected encephalitis. NAs are usually extracted with methods dedicated to either DNA or RNA.

While most laboratories use NA extraction kits with similar performance, gene amplification methods are highly diverse. The polymerase chain reaction (PCR) is the most common technique, but - for any given agent - several primer sets targeting different genes have been proposed by different authors. In addition, protocols differ with regard to reaction conditions, techniques for confirming amplified products, virus strains used as positive controls. Over the last few years, commercial methods for the most common viral agents have been introduced by major diagnostic Companies and are being evaluated the world over. Table 3 lists encephalitis agents (some not examined in this review) with selected diagnostic molecular methods and relevant references. A positive PCR result must always be considered in conjunction with clinical symptoms and signs prior to establishing a diagnosis. A negative RT-PCR result indicates only the absence of the agent being investigated in the sample, and does not exclude the suspected diagnosis. Equivocal results are those that fall between the lowest limit of detection and the background level. These can not be determined to be positive or negative. Qualitative PCR and RT-PCR are the amplification methods most frequently used. Both use thermostable DNA polymerases, specific primer sets, and dedicated thermocycling profiles. Amplicons are detected by gel electrophoresis and/or by hybridisation with a labelled probe.
Real-time amplification (a technique that allows quantification of amplified products) needs one or more primer sets plus photo-emitting probe(s) or, alternatively, a primer set plus a fluorescent dye that binds double-stranded DNA (e.g., SYBR Green). A recently proposed method is the loopmediated isothermal amplification (LAMP) assay. LAMP uses six or more primers that target a single gene. Its efficacy, sensitivity, and simplicity have been proved for CMV [63].

In clinical practice, laboratory diagnosis of viral encephalitis remains difficult due to the need of detecting a wide variety of agents in a short time. Multiplex PCR methods (i.e., methods capable of detecting multiple targets in a single test) have been proposed [64-67], but are rarely used. Notably, one system would allow the simultaneous detection of many enterovirus types, some herpesviruses and selected flaviviruses [65]. The specificity and sensitivity of this system, however, have not been documented.

\section{Neuroimaging}

Neuroimaging plays an important role in detecting inflammatory lesions of brain and meninges, since visualisation of typical lesion patterns does contribute to diagnosis.

In HSE brain CT scan reveals hypodense, contrastenhancing lesions in antero- and medial temporal and in inferior frontal regions. Oedema and mass effect occur in $80 \%$ of cases. Brain MRI is superior to CT scan in detecting necrosis in the orbitofrontal and medial temporal lobe, and in the insulae. Necrosis is demonstrated by increased signalling within the first 48 hours on T2-weighted (T2WI) or fluidattenuated inversion recovery (FLAIR) sequences [68] (Fig. 1), with decreased $T 1$ signal and variable enhancement. Diffusion-weighted imaging (DWI) is even more sensitive than T2WI or FLAIR in detecting early cortical lesions in HSE, both in infants and adults [69]. Diffusion abnormalities disappear within 14 days after onset, whereas hyperintensities on T2WI persist [69].

In HHV-6 encephalitis, MRI shows predominantly mesial temporal lobe abnormalities, including T2 signal hyperintensities and early volume loss in the hippocampus [70, 71]. DW-MRI is a promising tool for early detection and for outcome prediction [72].

EBV encephalitis in adult immunocompetent patients produces normal or mildly swollen brain on MRI, while in infants, due to characteristic tropism to deep grey nuclei, a pattern of increased signal on T2WI in the bilateral thalami and basal ganglia is observed.

In acute measles encephalitis, T2WI reveals cortical oedema and bilateral symmetric hyperintense lesions in putamen and caudate nuclei as well as in centrum semiovale. Contrast enhancement may appear in cortical areas and leptomeninges [73]. In early stages of SSPE, MR spectroscopy demonstrates increased choline/creatine ratios suggestive of asymmetrical inflammation in parieto-occipital corticosubcortical regions. In the late stages, conventional MRI discloses symmetrical periventricular hyperintense changes on T2WI [74].

In patients with TBE, pathological T2-weighted and FLAIR MRI changes can be observed in almost $20 \%$ of 
Table 3. Molecular Methods for Detecting the Main Agents of Viral Encephalitis [References in Square Brackets]

(a) DNA Viruses

\begin{tabular}{|c|c|c|c|c|c|c|}
\hline & \multirow[t]{2}{*}{ Virus } & \multicolumn{5}{|c|}{ Gene Amplification Method } \\
\hline & & Qualitative PCR & Quantitative PCR & Multiplex PCR & Other Techniques & \\
\hline \multirow{5}{*}{ 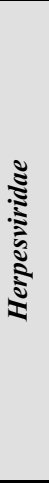 } & $\begin{array}{l}\text { Herpes Simplex } \\
\text { Virus (HSV) }\end{array}$ & $\begin{array}{l}\text { Target gene: } D N A \\
\text { polymerase }[61]\end{array}$ & $\begin{array}{l}\text { Target gene: US4 } \\
{[99]}\end{array}$ & \multirow{5}{*}{$\begin{array}{l}\text { Target region: } \\
\text { herpesvirus } D N A \\
\text { polymerase. Si- } \\
\text { multaneous detec- } \\
\text { tion of enterovi- } \\
\text { ruses, herpesvi- } \\
\text { ruses and flavivi- } \\
\text { ruses. Broadly } \\
\text { reactive primers } \\
\text { for the three fam- } \\
\text { ily, then DNA } \\
\text { probe array to } \\
\text { differentiate virus } \\
\text { species [65] }\end{array}$} & $\begin{array}{l}\text { Target gene: DNA polymerase. } \\
\text { PCR and chemiluminescent dot }\end{array}$ & \multirow{7}{*}{$\begin{array}{l}\text { DNA microar- } \\
\text { ray: } \\
38 \text { target genes } \\
\text { for } 13 \text { encepha- } \\
\text { litis-producing } \\
\text { viruses [104] }\end{array}$} \\
\hline & $\begin{array}{l}\text { Varicella-Zoster } \\
\text { Virus (VZV) }\end{array}$ & $\begin{array}{l}\text { Target gene: } g p 29 \\
\text { [61] }\end{array}$ & $\begin{array}{l}\text { Target region: } \\
\text { ORF38 [99] }\end{array}$ & & $\begin{array}{l}\text { blot hybridization or hetroduplex } \\
\text { mobility shift assay. Detection of }\end{array}$ & \\
\hline & $\begin{array}{l}\text { Epstein-Barr Vi- } \\
\text { rus (EBV) }\end{array}$ & $\begin{array}{l}\text { Target gene: } g p 220 \\
{[61]}\end{array}$ & $\begin{array}{l}\text { Target region: } \\
\text { BNT143 [99] }\end{array}$ & & $\begin{array}{l}\text { herpesviruses and species identifi- } \\
\text { cation [101] }\end{array}$ & \\
\hline & $\begin{array}{l}\text { Cytomegalo Vi- } \\
\text { rus (CMV) }\end{array}$ & Target gene: $M I E[61]$ & $\begin{array}{l}\text { Target genes: } \\
\text { CMV, UL54; HHV- }\end{array}$ & & Target gene: $g B$. LAMP [63] & \\
\hline & $\begin{array}{l}\text { Human Herpes } \\
\text { Virus-6 (HHV-6) }\end{array}$ & $\begin{array}{l}\text { Target gene: U86, } \\
\text { U95 [98] }\end{array}$ & 6, U56 [100] & & $\begin{array}{l}\text { Target gene: } U 67 \text {. Viral load in } \\
\text { CSF, whole blood and serum. Dif- } \\
\text { ferentiation between primary in- } \\
\text { fection and viral integration. Dis- } \\
\text { tinction of } 6 \mathrm{~A} / 6 \mathrm{~B} \text { variants } \\
\text { through restriction analysis [102] }\end{array}$ & \\
\hline \multirow{2}{*}{ 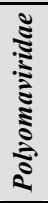 } & $\mathrm{JCV}$ & & $\begin{array}{l}\text { Target gene: late } \\
m R N A[99]\end{array}$ & \multirow[t]{2}{*}{$\begin{array}{l}\text { Target gene: } T \\
\text { large antigen }[64]\end{array}$} & \multirow{2}{*}{$\begin{array}{l}\text { PCR and colorimetric hybridiza- } \\
\text { tion assay for differential detection } \\
\text { of JC and BK virus genomes } \\
\text { [103]. Commercially available. }\end{array}$} & \\
\hline & BKV & & $\begin{array}{l}\text { Target gene: } V P 3 \\
\text { [99] }\end{array}$ & & & \\
\hline 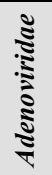 & Adenovirus & & $\begin{array}{l}\text { Target region: L2p5 } \\
\text { precursor, E1B, L5 } \\
\text { pVI, hexon gene } \\
{[99]}\end{array}$ & & & \\
\hline
\end{tabular}

(b) RNA Viruses

\begin{tabular}{|c|c|c|c|c|c|}
\hline & \multirow{2}{*}{ Virus } & \multicolumn{4}{|c|}{ Gene Amplification Method } \\
\hline & & Qualitative PCR & Quantitative PCR & Multiplex PCR & Other Techniques \\
\hline 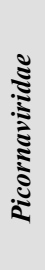 & $\begin{array}{c}\text { Enteroviruses (EV) } \\
\text { Polio and Several Non- } \\
\text { Polio EV are Included } \\
\text { EV71 }\end{array}$ & $\begin{array}{l}\text { Target gene: VP3-VPl. } \\
\text { Seminested PCR. Species } \\
\text { identification by sequencing } \\
\text { [105] } \\
\text { Target genes: } 5 \text { 'UTR for } \\
\text { detection [106]. Species } \\
\text { identification by microarray } \\
\text { technology [107] }\end{array}$ & $\begin{array}{l}\text { Target region: 5'UTR. } \\
\text { Detection of all EV } \\
{[109]}\end{array}$ & $\begin{array}{l}\text { Target region: 5'UTR. Simulta- } \\
\text { neous detection of enteroviruses, } \\
\text { herpesviruses and flaviviruses. } \\
\text { Broadly reactive primers for the } \\
\text { three family, then DNA probe } \\
\text { array to differentiate virus species } \\
\text { [65] }\end{array}$ & \\
\hline 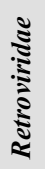 & $\begin{array}{c}\text { Human Immunodefi- } \\
\text { ciency Virus-1/2 (HIV- } \\
1 / 2)\end{array}$ & Commercial methods & $\begin{array}{l}\text { Commercial methods } \\
{[110]}\end{array}$ & & $\begin{array}{l}\text { Real-time PCR-based } \\
\text { point mutation assay } \\
\text { for detection of drug } \\
\text { resistance mutations } \\
\text { [115] }\end{array}$ \\
\hline 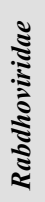 & Rabies & & $\begin{array}{l}\text { Target gene: } N \text {. Quanti- } \\
\text { tative detection and } \\
\text { distinction of different } \\
\text { genotypes [111] }\end{array}$ & & \\
\hline 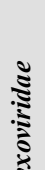 & Mumps & $\begin{array}{l}\text { Target gene: } S H . \text { Nested } \\
\text { PCR and sequencing to per- } \\
\text { form genetic classification } \\
{[108]}\end{array}$ & $\begin{array}{l}\text { Target gene: } S H \text {. One } \\
\text { step assay with internal } \\
\text { controls for nucleic } \\
\text { acid extraction and } \\
\text { PCR inhibitors [112] }\end{array}$ & $\begin{array}{l}\text { Target gene: } H N \text {; RT-LAMP } \\
\text { [113] }\end{array}$ & $\begin{array}{l}\text { DNA microarray: } 38 \\
\text { target genes for } 13 \\
\text { encephalitis-producing } \\
\text { viruses [104] }\end{array}$ \\
\hline$\stackrel{\Sigma}{5}$ & Measles & & & $\begin{array}{l}\text { Target gene: } N \text {. Real Time ARMS } \\
\text { PCR: six primer sets; genotypes } \\
\text { differentiated by melting curve } \\
\text { analysis [114] }\end{array}$ & \\
\hline
\end{tabular}


(Table 3) contd.....

(c) Arbovirus Group (RNA Agents)

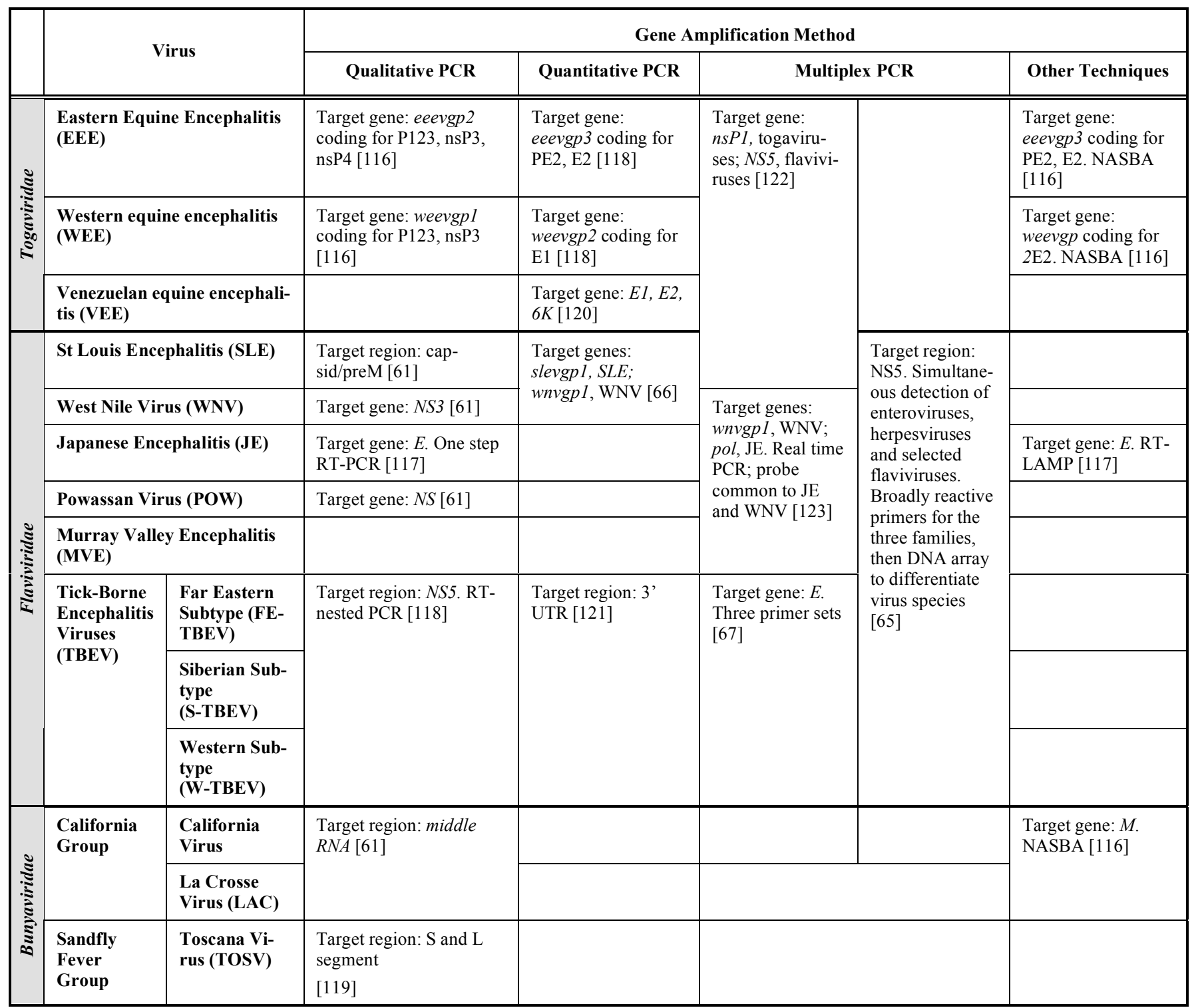

Abbreviations: PCR: polymerase chain reaction; RT-PCR: reverse transcription PCR; LAMP: loop-mediated isothermal amplification; NASBA: nucleic acid sequence-based amplification; Real time ARMS PCR: real-time amplification refractory mutation system PCR.

cases. Bilateral involvement of thalamus, and abnormalities of cerebellum, brain stem, basal ganglia, spinal cord are observed $[75,76]$.

Although the diagnosis of rabies is mostly clinical, MRI can be helpful. Both paralytic and encephalitic forms have similar distribution of mild T2 hyperintensities involving the brain stem, hippocampus, hypothalamus, deep and subcortical white matter, cerebral cortical grey matter, and basal ganglia. Alterations vary in different stages of the disease [77].

\section{Management}

The general management is essentially supportive and in severe cases must be in a high dependency or intensive care unit. Focal and generalised seizures need to be treated effectively with anticonvulsants intravenously. Raised intracranial pressure must be treated with intravenous mannitol and/or steroids. In the case of rapidly increasing intracranial pressure with clinical deterioration unresponsive to medical treatment, surgical decompression can be lifesaving. Other complications such as secondary bacterial infections, aspiration pneumonia, respiratory failure, cardiac abnormalities, fluid and electrolyte imbalance must be detected early and treated appropriately.

Herpesvirus-related encephalitis can be treated with a potentially effective antiviral therapy. The administration of acyclovir (within 48 hours of the onset of symptoms) at a dose of $10 \mathrm{mg} / \mathrm{kg}$ bw intravenously thrice per day for 14 days (21 days in immunocompromised hosts) reduces both the mortality rate and long-term severe neurological consequences in patients with HSE [78, 79]. However, mortality remains high $(14 \%$, increasing to $25.4 \%$ by the end of the 

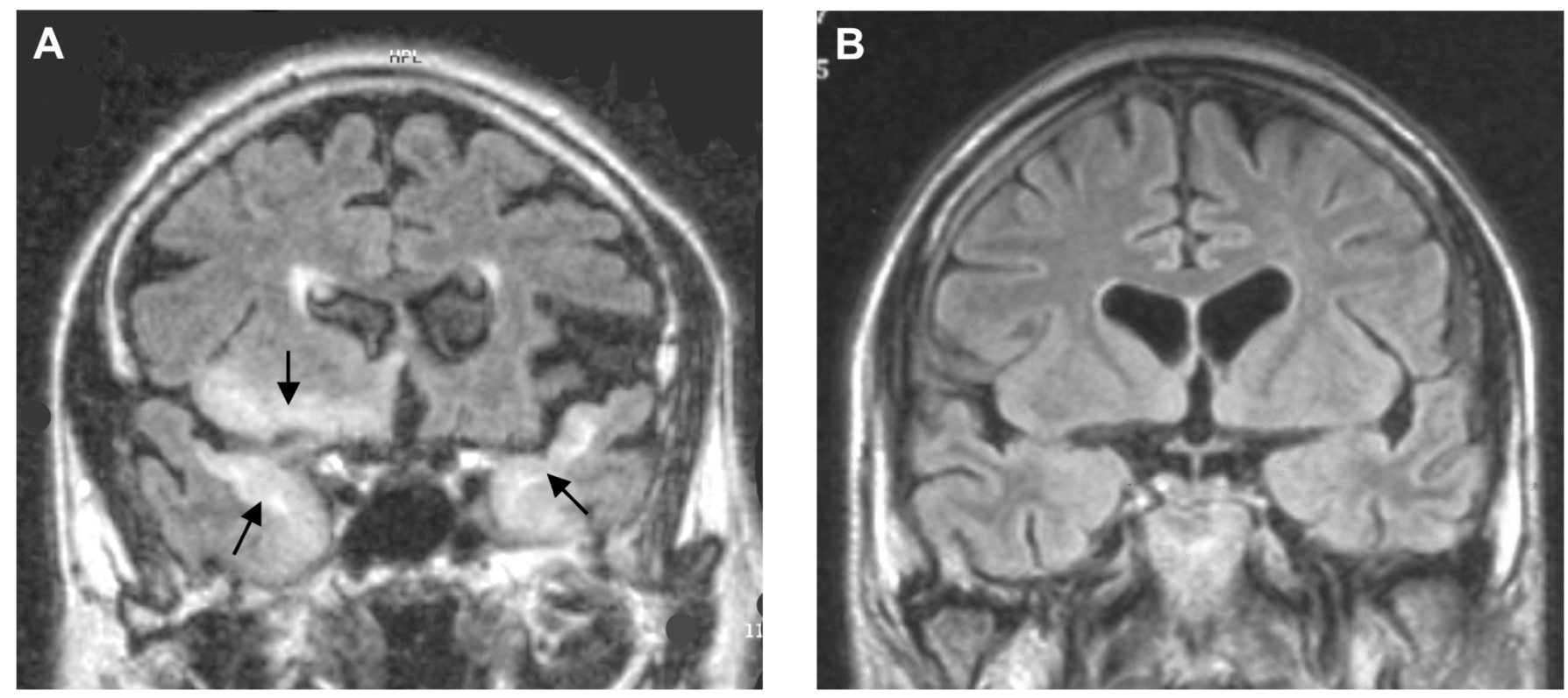

Fig. (1). Coronal fluid-attenuated inversion recovery (FLAIR) MRI scan demonstrates: bilateral involvement of medial temporal lobes and right orbitofrontal region (arrows) in one case of HSV-1 encephalitis (A), and normal image of one age-matched control (B).

first year after treatment in Sweden over an 11 years period) [80], especially in patients with Glasgow coma score lower than 6. Patients under 30 years of age and with a Glasgow coma score above 10 have the best outcome. In immunocompetent patients, herpesvirus resistance is rare and generally does not correlate with clinical outcome [81]. High dose steroids may be helpful in selected cases in children, especially when a biphasic course or relapses occur [82, 83].

In VZV encephalitis, the treatment benefit of acyclovir used routinely in immunologically competent children has not been proved. IV methylprednisolone can be given to patients who present with neurological deficits with a delay after onset ( $>7$ days) as these are likely to be cases of ADEM.

EBV encephalitis has no effective therapy (antiviral agents, immunoglobulins and steroids are ineffective). Different antivirals (ganciclovir, foscarnet and cidofovir) have been reportedly useful in few cases of HHV-6 encephalitis, but no clinical trials have been published [84]. No therapy exists for enteroviral encephalitis, although the broadspectrum antipicornavirus drug pleconaril might be an option in the future [85].

Various antiviral and immunomodulatory agents have been used occasionally to treat SSPE with contradictory results. Encouraging results were reported in a multicenter study with a 6-month follow-up evaluating oral inosiplex (isoprinosine) alone or combined with intraventricular IFN$\alpha 2 b$ therapy [86], but other studies are needed to confirm these data.

Rabies encephalitis is progressive and fatal, and therapy is largely palliative. Although survival has been reported in isolated cases of symptomatic patients, all of those patients had received either pre-or postexposure prophylaxis and none had positive test results for rabies virus [87-92]. Disabling neurologic sequelae followed in nearly all of these survivors. In 2005, Willoughby and colleagues described the survival of a nonvaccinated young girl with encephalitic rabies following an aggressive treatment that included thera- peutic coma, antiviral therapy and intensive care support [93]. The strategy, known as the Milwaukee Protocol, involves administration of ketamine, midazolam, amantadine, ribavirin and phenobarbitol, and is based on the idea that, given sufficient time, antiviral and antiexcitatory therapy will permit for viral clearance and clinical recovery. However, in the case described by Willoughby and colleagues, the rabies virus was never isolated and diagnosis was based on patient history, clinical findings and detection of anti-rabies virus antibodies in the blood and cerebrospinal fluid. Six additional cases of human rabies treated with the Milwaukee Protocol have been described [94-97]. None of the patients had received postexposure prophylaxis, all patients presented with clinical disease, and none survived. In spite of the detection of anti-rabies virus antibodies in these patients and of evidence of viral clearance, autopsies of most of the patients still revealed the presence of the rabies virus. In conclusion, at present rabies encephalitis must continue to be regarded as an incurable condition.

\section{CONCLUSIONS}

Viral encephalitis continues to pose many difficulties with regard to diagnosis and management. In spite of the sophisticated imaging and molecular methods today available, too often a cause is not identified. Supportive therapy to control seizures, respiratory arrest, cerebral oedema and to prevent deep vein thrombosis, aspiration pneumonia, bacterial infections, gastrointestinal bleeding as well as disseminated intravascular coagulation still represent the mainstay of treatment. The pathogenesis remains largely elusive, and only one form (HSE) can benefit from treatment. The use of steroids as adjunctive therapy continues to be controversial, although a number of reports have shown clinical benefits. Novel methods have been recently proposed for viral identification; thus it is hoped that random DNA amplification coupled to other molecular techniques $[87,88]$ will allow detection of the multiple agents of encephalitis. 
Much needs to be done to improve the prognosis of viral encephalitis. Unfortunately, the rarity of the disease will likely prevent substantial efforts by drug companies to develop novel and more targeted therapies.

\section{SEARCH STRATEGY AND SELECTION CRITERIA}

Data for this review were identified by searches of Medline, Current Contents, and references from relevant articles; numerous articles were identified through searches of the extensive files of the authors. Search terms were "encephalitis" or "viral encephalitis" and "etiology", "pathogenesis", "diagnosis", "symptoms", "investigation", "radiology", "computerised tomography", "nuclear magnetic resonance", "positron emission tomography", "single photon emission tomography", "pathology", "therapy", "antiviral therapy", "polymerase chain reaction", "virology", "cerebrospinal fluid", "EBV", "enteroviruses", "herpes simplex virus", "herpes zoster virus", "HHV-6", "measles", "rabies", "SSPE", "West Nile Virus" or "tick borne". Only English language papers published from 1960 to September 2008 were reviewed.

\section{REFERENCES}

[1] Granerod J, Crowcroft NS. The epidemiology of acute encephalitis. Neuropsychol Rehabil 2007; 17: 406-28.

[2] Koskiniemi M, Rantalaiho T, Piiparinen H, et al. Infections of the central nervous system of suspected viral origin: a collaborative study from Finland. J Neurovirol 2001; 7: 400-08.

[3] Kupila L, Vuorinen T, Vainionpää R, Hukkanen V, Marttila RJ, Kotilainen P. Etiology of aseptic meningitis and encephalitis in an adult population. Neurology 2006; 66: 75-80.

[4] Whitley RJ. Herpes simplex encephalitis: Adolescents and adults. Antiviral Res 2006; 71: 141-48.

[5] Longson M. The general nature of viral encephalitis in the United Kingdom. In: Ellis LS, Ed. Viral Diseases of the Central Nervous System. London, Bailliere Tindall 1984.

[6] Skoldenberg B, Forsgren M, Alestig K, et al. Acyclovir vs vidarabine in herpes simplex encephalitis: a randomized multicentre study in consecutive Swedish patients. Lancet 1984; 2: 707-11.

[7] Whitley RJ, Soong SJ, Linneman Jr C, Liu C, Pazin G, Alford CA. The National Institute of Allergy and Infectious Diseases Collaborative Antiviral Study Group. Herpes simplex encephalitis: clinical assessment. JAMA 1982; 247: 317-20.

[8] Johnson RT. The pathogenesis of acute viral encephalitis and postinfectious encephalitis. J Infect Dis 1987; 155: 359-64.

[9] Johnson RT. Viral Infections of the Nervous System. 2nd ed. Philadelphia: Lippincott-Raven Publishers, 1998.

[10] Johnson RT, Mims CA. Pathogenesis of viral infections of the nervous system. N Engl J Med 1968; 278: 23-30.

[11] Baringer JR, Pisani P. Herpes simplex virus genomes in human nervous system tissue analyzed by polymerase chain reaction. Ann Neurol 1994; 36: 823-29.

[12] Jamieson GA, Maitland NJ, Wilcock GK, Craske J, Itzhaki RF. Latent herpes simplex virus type 1 in normal and Alzheimer's disease brains. J Med Virol 1991; 33: 224-27.

[13] Nahmias AJ, Whitley RJ, Visintine AN, Takei Y, Alford Jr CA. The National Institute of Allergy and Infectious Diseases Collaborative Antiviral Study Group. Herpes simplex encephalitis: laboratory evaluations and their diagnostic significance. J Infect Dis 1982; 145: 829-36.

[14] Whitley RJ, Lakeman AD, Nahmias AJ, Roizman B. DNA restriction-enzyme analysis of herpes simplex virus isolates obtained from patients with encephalitis. New Engl J Med 1982; 307: 106062.

[15] Twomey JA, Barker CM, Robinson G, Howell DA. Olfactory mucosa in herpes simplex encephalitis. J Neurol Neurosurg Psychiatry 1979; 42: 983-87.

[16] Ojeda VJ, Archer M, Robertson TA, Bucens MR. Necropsy study of olfactory portal of entry in herpes simplex encephalitis. Med J Aust 1983; 1: 79-81.
[17] Stroop WG, Schaefer DC. Production of encephalitis restricted to the temporal lobes by experimental reactivation of herpes simplex virus. J Infect Dis 1986; 153: 721-31.

[18] Schlitt M, Lakeman FD, Wilson ER, et al. A rabbit model of focal herpes simplex encephalitis. J Infect Dis 1986; 153: 732-35.

[19] Barnes DW, Whitley RJ. CNS disease associated with varicella zoster virus and herpes simplex virus infection. Neurol Clin 1986; 4: 265-83.

[20] Kupila L, Vuorinen T, Vainionpää R, Hukkanen V, Marttila RJ, Kotilainen P. Etiology of aseptic meningitis and encephalitis in an adult population. Neurology 2006; 66: 75-80.

[21] Yang T-T, Huang L-M, Lu C-Y, et al. Clinical features and factors of unfavourable outcomes for non-polio enterovirus infection of the central nervous system in northern Taiwan, 1994-2003. J Microbiol Immunol Infect 2005; 38: 417-24.

[22] Preblud SR. Age specific risks of varicella complications. Paediatrics 1981; 68: 14-17

[23] Johnson R, Milbourn PE. Central nervous system manifestations of chickenpox. Can Med Assoc J 1970; 102: 831-34.

[24] McCormick WR, Rodnitzky RL, Schochet SS Jr, McKee AP. Varicella-zoster encephalomyelitis: A morphological and virological study. Arch Neurol 1969; 21: 559-70.

[25] Grose C, Henle G, Feorino PM. Primary Epstein-Barr virus infections in acute neurologic disease. N Engl J Med 1975; 292: 392-95.

[26] Domachowske JB, Cunningham CK, Cummings DL, Crosley CJ, Hannan WP, Weiner LB. Acute manifestations and neurologic sequelae of Epstein-Barr virus encephalitis in children. Pediatr Infect Dis J 1996; 15: 871-75.

[27] Francisci D, Sensini A, Fratini D, et al. Acute fatal necrotizing hemorrhagic encephalitis caused by Epstein-Barr virus in a young adult immunocompetent man. J Neurovirol 2004 ; 10: 414-17.

[28] Okuno T, Takahashi K, Balachandra K, et al. Seroepidemiology of human herpesvirus 6 infection in normal children and adults. J Clin Microbiol 1989; 27: 651-53.

[29] Chan PK, Ng HK, Hui M, Cheng AF. Prevalence and distribution of human herpesvirus 6 variants $\mathrm{A}$ and $\mathrm{B}$ in adult human brain. J Med Virol 2001; 64: 42-46.

[30] Seeley WW, Marty FM, Holmes TM, et al. Post-transplant acute limbic encephalitis: clinical features and relationship to HHV6. Neurology 2007; 69: 156-65.

[31] Crawford JR, Kadom N, Santi MR, Mariani B, Lavenstein BL. Human herpesvirus 6 rhombencephalitis in immunocompetent children. J Child Neurol 2007; 22: 1260-68.

[32] Novoa LJ, Nagra RM, Nakawatase T, Edwards-Lee T, Tourtellotte WW, Cornford ME. Fulminant demyelinating encephalomyelitis associated with productive HHV-6 infection in an immunocompetent adult. J Med Virol 1997; 52: 301-08.

[33] McCullers JA, Lakeman FD, Whitley RJ. Human herpesvirus 6 is associated with focal encephalitis. Clin Infect Dis 1995; 21: 57176.

[34] Portolani M, Pecorari M, Tamassia MG, et al. Case of fatal encephalitis by HHV-6 variant A. J Med Virol 2001; 65: 133-37.

[35] Losada I, Pozo F, Tenorio A, Damaso D. Meningoencephalitis caused by HHV-6 in a previously healthy immunocompetent adult. Med Clin (Barc) 2003; 120: 357.

[36] Beovic B, Pecaric-Meglic N, Marin J, et al. Fatal human herpesvirus 6-associated multifocal meningoencephalitis in an adult female patient. Scand J Infect Dis 2001; 33: 942-44.

[37] Torre D, Speranza F, Martegani R, et al. Meningoencephalitis caused by human herpesvirus 6 in an immunocompetent adult patient: case report and review of the literature. Infection 1998; 26: 402-04.

[38] Kaiser R. The clinical and epidemiological profile of tick-borne encephalitis in southern Germany 1994-98: a prospective study of 656 patients. Brain 1999; 122: 2067-78.

[39] Dumpis U, Crook D, Oksi J. Tick-borne encephalitis. Clin Infect Dis 1999; 28: 882-90.

[40] Schneider-Schaulies J, ter Meulen V, Schneider-Schaulies S. Measles infection of the central nervous system. J Neurovirol 2003; 9: 247-52.

[41] Fazakerley JK, Walker R. Virus demyelination. J Neurovirol 2003; 9: 148-64.

[42] Plotkin SA. Rabies. Clin Infect Dis 2000; 30: 4-12.

[43] Hubalek Z, Halouzka J, Juricova Z. West Nile fever in Czechland. Emerg Infect Dis 1999; 5: 594-95. 
[44] Mostashari F, Bunning M, Kitsutani P, et al. Epidemic West Nile encephalitis, New York, 1999: results of a household- based seroepidemiological survey. Lancet 2001; 358: 261-64.

[45] Hayes E, Gubler D. West Nile Virus: Epidemiology and clinical features of an emerging epidemic in the United States. Annu Rev Med 2006; 57: 181-94.

[46] Bode A, Sejvar J, Pape W, Campbell G. West Nile virus disease: a descriptive study of 228 patients hospitalized in a 4-county region of Colorado in 2003. Clin Infect Dis 2006; 42: 1234-40.

[47] Sejvar JJ, Haddad MB, Tierney BC, et al. Neurologic manifestations and outcome of West Nile virus infection. JAMA 2003; 290: 511-15.

[48] Tambussi G, Gori A, Capiluppi B, et al. Neurological symptoms during primary human immunodeficiency virus (HIV) infection correlate with high levels of HIV RNA in cerebrospinal fluid. Clin Infect Dis 2000; 30: 962-65.

[49] Wendel KA, McArthur JC. Acute meningoencephalitis in chronic human immunodeficiency virus (HIV) infection: putative central nervous system escape of HIV replication. Clin Infect Dis 2003; 37: 1107-11.

[50] Menge T, Kieseier BC, Nessler S, Hemmer B, Hartung HP, Stüve O. Acute disseminated encephalomyelitis: an acute hit against the brain. Curr Opin Neurol 2007; 20: 247-54.

[51] Hughes RAC, Cornblath DR. Guillain-Barré syndrome. Lancet 2005; 366: 1653-66.

[52] Steiner I, Kennedy PG, Pachner AR. The neurotropic herpes viruses: herpes simplex and varicella-zoster. Lancet Neurol 2007; 6: 1015-28.

[53] Kennedy PG. Viral encephalitis. J Neurol 2005; 252: 268-72.

[54] Schott JM. Limbic encephalitis: a clinician's guide. Practical Neurology 2006; 6: 143-53.

[55] Castillo P, Woodruff B, Caselli R, et al. Steroid-responsive encephalopathy associated with autoimmune thyroiditis. Arch Neurol 2006; 63: 197-202.

[56] Caselli RJ, Boeve BF, Scheithauer BW, O'Duffy JD, Hunder GG. Nonvasculitic autoimmune inflammatory meningoencephalitis (NAIM): a reversible form of encephalopathy. Neurology 1999; 53 : 1579-81.

[57] Darnell RB, Posner JB. Paraneoplastic syndromes involving the nervous system. N Engl J Med 2003; 349: 1543-54.

[58] Tüzün E, Dalmau J. Limbic encephalitis and variants: classification, diagnosis and treatment. Neurologist 2007; 13: 261-71.

[59] Wainwright MS, Martin PL, Morse RP, et al. Human herpesvirus 6 limbic encephalitis after stem cell transplantation. Ann Neurol 2001; 50: 612-19.

[60] Huang CC, Liu CC, Chang YC, Chen CY, Wang ST, Yeh TF. Neurologic complications in children with enterovirus 71 infection. $\mathrm{N}$ Engl J Med 1999; 341: 936-42.

[61] Huang C, Morse D, Slater B, et al. Multiple-year experience in the diagnosis of viral central nervous system infections with a panel of polymerase chain reaction assays for detection of 11 viruses. Clin Infect Dis 2004; 39: 630-35.

[62] Cinque P, Bossolasco S, Lundkvist A. Molecular analysis of cerebrospinal fluid in viral diseases of the central nervous system. J Clin Virol 2003; 26: 1-28.

[63] Suzuki R, Yoshikawa T, Ihira M, et al. Development of the loopmediated isothermal amplification method for rapid detection of cytomegalovirus DNA. J Virol Methods 2006; 132: 216-21.

[64] Fedele CG, Ciardi M, Delia S, Echevarria JM, Tenorio A. Multiplex polymerase chain reaction for the simultaneous detection and typing of polyomavirus JC, BK and SV40 DNA in clinical samples. J Virol Methods 1999; 82: 137-44.

[65] Korimbocus J, Scaramozzino N, Lacroix B, Crance JM, Garin D, Vernet G. DNA probe array for the simultaneous identification of herpesviruses, enteroviruses, and flaviviruses. J Clin Microbiol 2005; 43: 3779-87.

[66] Dyer J, Chisenhall DM, Mores CN. A multiplexed TaqMan assay for the detection of arthropod-borne flaviviruses. J Virol Methods 2007; 145: 9-13.

[67] Ruzek D, Stastna H, Kopecky J, Golovljova I, Grubhoffer L. Rapid subtyping of tick-borne encephalitis virus isolates using multiplex RT-PCR. J Virol Methods 2007; 144: 133-37.

[68] Maschke M, Kastrup O, Forsting M, Diener HC. Update on neuroimaging in infectious central nervous system disease. Curr Opin Neurol 2004; 17: 475-80.
[69] Kuker W, Ngele T, Schmidt F, Heckl S, Herrlinger U. Diffusion weighted MRI in herpes simplex encephalitis: a report of three cases. Neuroradiology 2004; 46: 122-25.

[70] Wainwright MS, Martin PL, Morse RP, et al. Human herpesvirus 6 limbic encephalitis after stem cell transplantation. Ann Neurol 2001; 50: 612-19.

[71] Zerr DM, Gupta D, Huang ML, Carter R, Corey L. Effect of antivirals on human herpesvirus 6 replication in hematopoietic stem cell transplant recipients. Clin Infect Dis 2002; 34: 309-17.

[72] Takaya J, Araki A, Kaneko K. Usefulness of diffusion-weighted MRI in human herpesvirus-6 encephalitis. Acta Paediatrica 2007; 96: $135-38$.

[73] Lee KY, Cho WH, Kim HD, Kim IO. Acute encephalitis associated with measles: MRI features. Neuroradiology 2003; 45: 100-6.

[74] Oztürk A, Gürses C, Baykan B, Gökyigit A, Eraksoy M. Subacute sclerosing panencephalitis: clinical and magnetic resonance imaging evaluation of 36 patients. J Child Neurol 2002; 17: 25-9.

[75] Kaiser R. The clinical and epidemiological profile of tick-borne encephalitis in southern Germany 1994-98: a prospective study of 656 patients. Brain 1999; 122: 2067-78.

[76] Bender A, Schulte-Altedorneburg G, Walther EU, Pfister H-W. Severe tick borne encephalitis with simultaneous brain stem, bithalamic, and spinal cord involvement documented by MRI. J Neurol Neurosurg Psychiatry 2005; 76: 135-37.

[77] Hemachudha T, Laothamatas J, Rupprecht CE. Human rabies: a disease of complex neuropathogenetic mechanisms and diagnostic challenges. Lancet Neurology 2002; 1: 101-09.

[78] Sköldenberg B, Forsgren M, Alestig K, et al. Acyclovir vs vidarabine in herpes simplex encephalitis. Randomised multicentre study in consecutive Swedish patients. Lancet 1984; 2: 707-11.

[79] Whitley RJ, Alford CA, Hirsch MS, et al. Vidarabine vs acyclovir therapy in herpes simplex encephalitis. N Engl J Med 1986; 314: 144-49.

[80] Hjalmarsson A, Blomqvist P, Skoldenberg B. Herpes simplex encephalitis in Sweden, 1990-2001: incidence, morbidity, and mortality. Clin Infect Dis 2007; 45: 875-80.

[81] Reusser P. Herpesvirus resistance to antiviral drugs: a review of the mechanism, clinical importance and therapeutic options. J Hosp Infect 1996; 33: 235-48.

[82] Musallam B, Matoth I, Wolf DG, Engelhard D, Averbuch D. Steroids for deteriorating herpes simplex virus encephalitis. Pediatr Neurol 2007; 37: 229-32.

[83] Pike MG, Kennedy CR, Neville BG, Levin M. Herpes simplex encephalitis with relapse. Arch Dis Child 1991; 66: 1242-44.

[84] Whitley RJ, Lakeman FD. Human herpesvirus 6 infection of the central nervous system: is it just a case of mistaken association? Clin Infect Dis 2005; 40: 894-95.

[85] Pevear DC, TullTM, Seipel ME, Groarke JM. Activity of Pleconaril against enteroviruses. Antimicrob Agents Chemother 1999; 43 2109-15.

[86] Gascon GG. International Consortium on Subacute Sclerosing Panencephalitis. Randomized treatment study of inosiplex vs combined inosiplex and intraventricular interferon-alpha in subacute sclerosing panencephalitis (SSPE): international multicenter study. J Child Neurol 2003; 18: 819-27.

[87] Alvarez L, Fajardo R, Lopez E, et al. Partial recovery from rabies in a nine-year-old boy. Pediatr Infect Dis J 1994; 13: 1154-55.

[88] Gode GR, Raju AV, Jayalakshmi TS, et al. Intensive care in rabies therapy. Clinical observations. Lancet 1976; 2: 6-8.

[89] Hattwick MA, Weis TT, Stechschulte CJ, et al. Recovery from rabies. A case report. Ann Intern Med 1972; 76: 931-42.

[90] Madhusudana SN, Nagaraj D, Uday M, et al. Partial recovery from rabies in a six-year-old girl. Int $\mathrm{J}$ Infect Dis 2002; 6: 85-6.

[91] Porras C, Barboza JJ, Fuenzalida E, et al. Recovery from rabies in man. Ann Intern Med 1976; 85: 44-8.

[92] US Centers for Disease Control and Prevention. Rabies in a laboratory worker — New York. MMWR Morb Mortal Wkly Rep 1977; 26: 183-84.

[93] Willoughby RE Jr, Tieves KS, Hoffman GM, et al. Survival after treatment of rabies with induction of coma. N Engl J Med 2005; 352: 2508-14.

[94] US Centers for Disease Control and Prevention. Human rabies Indiana and California, 2006. MMWR Morb Mortal Wkly Rep 2007; 56: 361-65. 
[95] Hemachudha T, Sunsaneewitayakul B, Desudchit T, et al. Failure of therapeutic coma and ketamine for therapy of human rabies. $\mathrm{J}$ Neurovirol 2006; 12: 407-09.

[96] Schmiedel S, Panning M, Lohse A, et al. Case report on fatal human rabies infection in Hamburg, Germany, March 2007. Euro Surveill 2007; 12: E070531.5.

[97] McDermid RC, Saxinger L, Lee B, et al. Human rabies encephalitis following bat exposure: failure of therapeutic coma. CMAJ 2008; 178: 557-61.

[98] Tavakoli NP, Nattanmai S, Hull R, et al. Detection and typing of human herpes virus 6 by molecular methods, in specimens from patients diagnosed with encephalitis/meningitis. J Clin Microbiol 2007; 45: 3972-78.

[99] Watzinger F, Suda M, Preuner S, et al. Real-time quantitative PCR assays for detection and monitoring of pathogenic human viruses in immunosuppressed pediatric patients. J Clin Microbiol 2004; 42: 5189-98.

[100] Sassenscheidt J, Rohayem J, Illmer T, Bandt D. Detection of betaherpesviruses in allogenic stem cell recipients by quantitative realtime PCR. J Virol Methods 2006; 138: 40-8.

[101] Hudnall SD, Chen T, Tyring SK. Species identification of all eight human herpesviruses with a single nested PCR assay. J Virol Methods 2004; 116: 19-26.

[102] Ward KN, Leong HN, Thiruchelvam AD, Atkinson CE, Clark DA. Human herpesvirus 6 DNA levels in cerebrospinal fluid due to primary infection differ from those due to chromosomal viral integration and have implications for diagnosis of encephalitis. J Clin Microbiol 2007; 45: 1298-304.

[103] Moret H, Brodard V, Barranger C, Jovenin N, Joannes M, Andreoletti L. New commercially available PCR and microplate hybridization assay for detection and differentiation of human polyomaviruses JC and BK in cerebrospinal fluid, serum, and urine samples. J Clin Microbiol 2006; 44: 1305-09.

[104] Boriskin YS, Rice PS, Stabler RA, et al. DNA microarrays for virus detection in cases of central nervous system infection. J Clin Microbiol 2004; 42: 5811-18.

[105] Nix WA, Oberste MS, Pallansch MA. Sensitive, seminested PCR amplification of VP1 sequences for direct identification of all enterovirus serotypes from original clinical specimens. J Clin Microbiol 2006; 44: 2698-704.

[106] Pérez-Vélez CM, Anderson MS, Robinson CC, et al. Outbreak of neurologic enterovirus type 71 disease: a diagnostic challenge. Clin Infect Dis 2007; 45: 950-7.

[107] Chen TC, Chen GW, Hsiung CA, et al. Combining multiplex reverse transcription-PCR and a diagnostic microarray to detect and differentiate enterovirus 71 and coxsackievirus A16. J Clin Microbiol 2006; 44: 2212-19.

[108] Palacios G, Jabado O, Cisterna D, et al. Molecular identification of mumps virus genotypes from clinical samples: standardized method of analysis. J Clin Microbiol 2005; 43: 1869-78.

[109] Nijhuis M, van Maarseveen N, Schuurman R, et al. Rapid and sensitive routine detection of all members of the genus enterovirus in different clinical specimens by real-time PCR. J Clin Microbiol 2002; 40: 3666-70.
[110] Swanson P, de Mendoza C, Joshi Y, et al. Impact of Human Immunodeficiency Virus Type 1 (HIV-1) Genetic Diversity on Performance of Four Commercial Viral Load Assays: LCx HIV RNA Quantitative, AMPLICOR HIV-1 MONITOR v1.5, VERSANT HIV-1 RNA 3.0, and NucliSens HIV-1 QT. J Clin Microbiol 2005; 43: $3860-8$.

[111] Wakeley PR, Johnson N, McElhinney LM, Marston D, Sawyer J, Fooks AR. Development of a real-time, differential RT-PCR TaqMan assay for lyssavirus genotypes 1, 5 and 6. Dev Biol (Basel) 2006; 126: 227-36.

[112] Boddicker JD, Rota PA, Kreman T, et al. Real-time reverse transcription-PCR assay for detection of mumps virus RNA in clinical specimens. J Clin Microbiol 2007; 45: 2902-08.

[113] Okafuji T, Yoshida N, Fujino M, et al. Rapid diagnostic method for detection of mumps virus genome by loop-mediated isothermal amplification. J Clin Microbiol 2005; 43: 1625-31.

[114] Waku-Kouomou D, Alla A, Blanquier B, et al. Genotyping measles virus by real-time amplification refractory mutation system PCR represents a rapid approach for measles outbreak investigations. J Clin Microbiol 2006; 44: 487-94.

[115] Johnson JA, Li JF, Wei X, et al. Simple PCR assays improve the sensitivity of HIV-1 subtype B drug resistance testing and allow linking of resistance mutations. PLoS ONE 2007; 2: e638.

[116] Lambert AJ, Martin DA, Lanciotti RS. Detection of North American eastern and western equine encephalitis viruses by nucleic acid amplification assays. J Clin Microbiol 2003; 41: 379-85.

[117] Parida MM, Santhosh SR, Dash PK, et al. Development and evaluation of reverse transcription-loop-mediated isothermal amplification assay for rapid and real-time detection of Japanese encephalitis virus. J Clin Microbiol 2006; 44: 4172-78.

[118] Saksida A, Duh D, Lotric-Furlan S, Strle F, Petrovec M, AvsicZupanc T. The importance of tick-borne encephalitis virus RNA detection for early differential diagnosis of tick-borne encephalitis. J Clin Virol 2005; 33: 331-35.

[119] Charrel RN, Gallian P, Navarro-Mari JM, et al. Emergence of Toscana virus in Europe. Emerg Infect Dis 2005; 11: 1657-63.

[120] Linssen B, Kinney RM, Aguilar P, et al. Development of reverse transcription-PCR assays specific for detection of equine encephalitis viruses. J Clin Microbiol 2000; 38: 1527-35.

[121] Schwaiger M, Cassinotti P. Development of a quantitative real-time RT-PCR assay with internal control for the laboratory detection of tick borne encephalitis virus (TBEV) RNA. J Clin Virol 2003; 27: 136-45.

[122] De Morais Bronzoni RV, Baleotti FG, Ribeiro Nogueira RM, Nunes M, Moraes Figueiredo LT. Duplex reverse transcription-PCR followed by nested PCR assays for detection and identification of Brazilian alphaviruses and flaviviruses. J Clin Microbiol 2005; 43: 696-702.

[123] Shirato K, Miyoshi H, Kariwa H, Takashima I. Detection of West Nile virus and Japanese encephalitis virus using real-time PCR with a probe common to both viruses. J Virol Methods 2005; 126: 119-25. 